\title{
Intercropping oil palm with food crops in Ghana: 1. Effect on nutrient dynamics, soil moisture retention and light interception
}

\author{
B. N. NUERTEY, I. K. OFORI \& F. M. TETTEH \\ (B. N. N.: CSIR-Oil Palm Research Institute, P. O. Box 74, Kusi-Kade, Ghana; I. K.O.: \\ Department of Crop Science, Faculty of Agriculture, University of Ghana, Legon, Ghana; F. M. T.: \\ CSIR-Soil Research Institute, Academy Post Office, Kwadaso-Kumasi, Ghana)
}

\begin{abstract}
Nutrient dynamics, soil moisture retention, and light interception by oil palm in different cropping systems were examined in an oil palm-food crop intercropping trial at the Oil Palm Research Institute, Kusi, in Ghana between 1999 and 2002. There were four treatments consisting of a sole oil palm with pueraria cover crop, and three oil palm-food intercrops: oil palm + maize + cassava; oil palm + maize + plantain; and oil palm + maize + maize. The treatments were arranged in a randomised complete block design with four replicates. Generally, oil palm + maize + maize and oil palm with pueraria cover crop seemed to have favoured higher soil moisture retention, nutrient uptake and accumulation, and light interception by the oil palm than what pertained with oil palm + maize + cassava and oil palm + maize + plantain treatments. Oil palm with maize planted in the major and minor seasons seems to be a better intercropping option to be recommended to farmers because the food crop does not affect the growth of the oil palm during the establishment phase, and could also provide revenue to defray part of the substantial capital outlay required for establishing oil palm plantation.
\end{abstract}

Original scientific paper. Received 06 Dec 05; revised 14 Mar 08.

Ghana Jnl agric. Sci. $\quad 42,43-54$ 


\section{Introduction}

In Ghana, oil palm is cultivated as a monocrop in the development of plantations, with Pueraria phaseoloides planted in the interrows. However, the smallholders intercrop food and cash crops in the oil palm, especially during the initial 3 years after planting the oil palm (Sparnaaij, 1991; Nuertey, 2000) for socio-economic reasons (Norman, 1974). Also, integration of food crop in oil palm cultivation has become necessary because most areas around the large oil palm estates in Ghana (Benso Oil Palm Plantation, BOPP; Twifo Oil Palm Plantation, TOPP; and Ghana Oil Palm Development Company, GOPDC; etc), which were once exporting food crops, now face food scarcity. The standard 8.8-m triangular spacing provides wide spaces between the young palms. Therefore, considerable waste of solar radiation, reduced land use efficiency, and weed problems ranging from transplanting to canopy closure are observed, which take up to 5 years. Such monocropping systems often require substantial initial capital outlay as in the establishment of oil palm plantations.

Within the socio-economic contexts, the physical environment in which the crop species compete for growth factors and resources imposes limitations. The climatic conditions in the whole of Ghana and West Africa are suboptimal for oil palm production (Rees, 1989). The long dry spell, which lasts for at least 3 months in the West African sub-region, creates water deficit that adversely affects the oil palm. The capacity of any soil as influenced by the cropping system to conserve soil moisture, especially during the dry season is, therefore, important. To fully use intercepted light, plants must be adequately supplied with water and mineral nutrition. Oil palm requires large quantities of nutrients to maintain high vegetative growth and yield. There has been increased emphasis on site-specific nutrient management to improve oil palm growth and productivity to match its potential to the site (Chew et al., 1992; Kee \& Chew, 1996). The soil supplies the bulk of these nutrients, and additives are only required to make up any shortage. $\mathrm{Ng} \&$ Thamboo (1967) used nutrient content of oil palm to estimate nutrient removal by oil palm. The adequacy or otherwise of nutrient supply to oil palm may be checked either through soil or plant tissue analysis. Certainly, these conditions influence the productivity of the oil palm. It is, therefore, necessary for scientific and practical interest to evaluate oil palm productivity under different cropping systems. The information gained from this study concerning use or conservation of water or both, nutrient and light resources would benefit the large estates and small-scale farmers.

\section{Materials and methods \\ Experimental design and treatments}

The experiment consisted of four treatments arranged in a randomised complete block design with four replications. The oil palm planting material used was tenera $(\mathrm{D} \times \mathrm{P}$ ex OPRI). Twelvemonth-old seedlings were transplanted in the field in April 1999. Each plot measured $35.2 \mathrm{~m} \times 22.7 \mathrm{~m}$ and carried 12 seedlings. Planting was done at a spacing of 8.8-m triangular (148 plants ha $\left.{ }^{-1}\right)$. The treatments were as follows:

(i) Oil palm + pueraria: oil palm inter-rows were seeded with a leguminous cover crop, Pueraria phaseoloides. The cover crop was seeded at $0.5 \mathrm{~kg}$ per plot in April 1999 after the seedlings were transplanted. This is a standard estate practice, which served as the control in the experiment. Fertilizer was applied to the oil palm seedlings 6 months after transplanting, and thereafter, in September every year. Nitrogen was applied at $42 \mathrm{~g}$ in the form of urea, phosphorus at $48 \mathrm{~g}$ as triple super phosphate, and potassium at $250 \mathrm{~g}$ per tree as muriate of potash (Anon., 1988).

(ii) Oil palm + maize + cassava: oil palm interrows were cropped with maize and cassava during the major seasons. Maize (var. Okomasa ex CRI) was first planted on 20th April 1999 at $0.7 \mathrm{~m} \times 0.5 \mathrm{~m}$ with three seeds 
per stand, but thinned to two at 1 week after emergence, resulting in a plant population of 3,780 per plot. There were 27 rows per plot. The cassava (a mixture of Nzema and Ankra varieties) was first planted on 6th May 1999, about 2 weeks after emergence of maize and spaced at $1 \mathrm{~m}$ within and between rows; thus, giving a plant population of 10,000 plants $\mathrm{ha}^{-1}$. Maize and cassava rows were spatially arranged on the same row as oil palm and in rows $0.7,1.4,2.1$, and 2.8 m equidistant from the palm row. The maize was harvested on 24th August. Cassava was harvested in March the following year.

The cycle was repeated every year for 4 years of experimentation.

(iii) Oil palm + maize + plantain: oil palm interrows were cropped with maize and plantain in the major season in 1999. The maize was planted and harvested in the same manner and time as in the previous treatment and at the same plant population. The plantain, false horn variety 'Apantu pa', was planted at 3-m triangular in the inter-rows of the oil palm; thus, giving 88 plants per plot or 1220 plants $\mathrm{ha}^{-1}$. The nearest plantain rows, with reference to the oil palm rows, were 1.2 m equidistant from the oil palm rows. After the first cycle maize, the plantain was maintained up to the third ratoon crop ending in January 2001.

(iv) Oil palm + maize + maize: oil palm interrows were cropped with maize in the major season, followed by maize in the minor season. Major season maize was first planted on 20th April and harvested on 24th August as for treatment (ii). The minor season maize was first planted on 6th September 1999 and harvested on 3rd January 2000. Spacing and plant population for major and minor season maize was the same as in treatment (ii). The cycle was also repeated every year for the 4 years of experimentation.

\section{Data collection}

Soil fertility status. To assess the dynamics of soil nutrient accumulation, soil sampling was undertaken before land clearing and after every cropping cycle at $0-15$ and $15-30 \mathrm{~cm}$ depths. The samples taken were air-dried, ground, and passed through a 2-mm mesh sieve.

Soil $p \mathrm{H}$ was determined in a 1:1 soil:water suspension using a $p \mathrm{H}$ meter with glass electrode.

Organic-C was determined by the WalkleyBlack dichromate method (Nelson \& Sommers, 1982). Total N was determined by the Kjeldahl method (Rowell, 1994). Available phosphorus was determined by the Bray's No.1 method, and potassium in $1.0 \mathrm{M} \mathrm{NH}_{4} \mathrm{OAc}$ extract was determined by flame photometry (Black, 1965).

Leaf nutrient dynamics. To determine the dynamics of oil palm nutrient uptake, leaf samples of the oil palm lamina from the central leaflets of Leaf No.17 were taken at 6-monthly interval.

The leaf samples were cleaned with cotton wool and distilled water, oven-dried at $60{ }^{\circ} \mathrm{C}$ for $72 \mathrm{~h}$, ground, and analysed for their nutrient contents. Total nitrogen was determined by the Kjeldahl method, phosphorus by the vanadomolybdate method, and potassium by flame photometry (Black, 1965).

Soil moisture status during the dry season. Soil moisture status was determined monthly over the dry season (November-March), which was the most critical period to assess moisture regimes under the various treatments. Soil samples were taken at 0-15 and 15-30 cm depths. Soil samples were collected in aluminium cans and covered immediately. The samples were then weighed before and after oven-drying at $105^{\circ} \mathrm{C}$ for $48 \mathrm{~h}$. Percentage soil moisture at field capacity was calculated from data using the equation:

$$
\frac{\mathrm{W}_{1}-\mathrm{W}_{2}}{\mathrm{~W}_{1}} \times 100
$$


where $\mathrm{W}_{1}$ and $\mathrm{W}_{2}$ are the fresh and dried weights of the soil sample, respectively (Rowell, 1994).

Light interception by the oil palm. Light interception was measured in the 4th year if the experiment was to study the influence of the various cropping systems on light interception by the oil palm canopies. Two solarimeters (tubes) were used. Each solarimeter was connected to a microvolt integrator $\left(\mathrm{NV}^{2}\right)$. One tube solarimeter was installed above the canopy of the palm, about $1 \mathrm{~m}$ above Leaf No.1; and the other was placed directly beneath the canopy. The tubes were installed and set or reset on the plots at $0930 \mathrm{~h}$ on each measurement day. Daily readings were taken hourly from 1030 to $1530 \mathrm{~h}$. Measurements from the two solarimeters were used to estimate percentage interception of solar irradiance by the oil palm. Solar irradiance above canopy was used as basis for comparison.

\section{Results}

Effects of intercropping on soil nutrient dynamics Soil acidity $(\mathrm{pH})$

Table 1 shows soil $p \mathrm{H}$ changes under the various oil palm-based cropping systems. In 2000, oil palm + maize + cassava treatment was significantly $(P<0.05)$ higher in soil $p \mathrm{H}$ than the other crop combinations. In 2001 and 2002, however, oil palm + maize + plantain treatment had the lowest $p \mathrm{H}$ values.

There were some increments with years in soil $p \mathrm{H}$ by 0.25 to 0.50 units for oil palm undercropped with pueraria. The oil palm intercropped with maize in the major and minor seasons also recorded increment in soil $p \mathrm{H}$ by 0.5 to 0.6 units. The treatment involving cassava had soil $p \mathrm{H}$ values almost the same throughout the test period. Growing of pueraria as cover crop in oil palm as well as intercropping oil palm with maize followed by maize led to increase in soil $p \mathrm{H}$ by 0.5 units.

\section{Soil organic matter}

Fig. 1 shows organic matter content of soil under various crop combinations. Changes in organic matter content among the treatments were not significantly different over the test period. Organic matter levels were generally moderate, and ranged from 2 to 2.6 per cent in the $0-15 \mathrm{~cm}$

TABLE 1

Effect of Intercropping Food Crops in Oil Palm on Dynamics of Soil pH from 1999 to 2002

\begin{tabular}{|c|c|c|c|c|}
\hline \multirow{3}{*}{ Crop combination } & \multicolumn{4}{|c|}{ Soil $\mathrm{pH}$ of cropping year } \\
\hline & 1999 & 2000 & 2001 & 2002 \\
\hline & \multicolumn{4}{|c|}{$0-15 \mathrm{~cm}$ soil depth } \\
\hline Oil palm + pueraria & 4.6 & 4.5 & 5.0 & 4.7 \\
\hline Oil palm + maize + cassava & 4.6 & 4.9 & 4.8 & 4.9 \\
\hline Oil palm + maize + plantain & 4.6 & 4.4 & 4.3 & 4.4 \\
\hline Oil palm + maize + maize & 4.6 & 4.5 & 5.1 & 5.0 \\
\hline \multirow[t]{2}{*}{$\operatorname{LSD}(P \leq 0.05)$} & - & 0.2 & 0.4 & 0.4 \\
\hline & \multicolumn{4}{|c|}{$15-30 \mathrm{~cm}$ soil depth } \\
\hline Oil palm + pueraria & 4.5 & 4.5 & 5.0 & 4.7 \\
\hline Oil palm + maize + cassava & 4.5 & 4.8 & 4.5 & 4.8 \\
\hline Oil palm + maize + plantain & 4.5 & 4.3 & 4.2 & 4.2 \\
\hline Oil palm + maize + maize & 4.5 & 4.5 & 5.0 & 4.9 \\
\hline $\operatorname{LSD}(P \leq 0.05)$ & - & 0.3 & 0.5 & 0.5 \\
\hline
\end{tabular}


soil layer. The values reduced with soil depth. Soil organic matter content decreased in all treatments with years of cultivation. The decline was highest in the oil palm + pueraria treatment after the 1st year of cultivation. However, at the end of the 3rd year of cropping, the oil palm + pueraria treatment had the highest organic matter content.

\section{Total nitrogen}

Total nitrogen values showed no significant differences among the means for the various cropping systems (Table 2). Values for the 0-15 $\mathrm{cm}$ depth were significantly higher than values for $15-30 \mathrm{~cm}$. The values were almost the same, decreasing or increasing slightly over the test period. At the end of the experiment, nitrogen levels were highest in the oil palm + pueraria treatment and least in the oil palm + maize + maize treatment. Total nitrogen content declined with depth in all the treatments. Subsoil total N content also followed the same trend of distribution as the surface soil total $\mathrm{N}$ content.

\section{Available phosphorus}

Table 3 shows the available phosphorus (P) levels as influenced by the various treatments. Available phosphorus levels for the $0-15 \mathrm{~cm}$ soil depth were significantly higher $(P \leq 0.05)$ than those for the $15-30 \mathrm{~cm}$ depth. The latter was only about 60 per cent of the former at the start of the studies in 1999. Available phosphorus content declined in all treatments with time of cultivation (Fig. 2). The decline was most pronounced in the oil palm + pueraria treatment $(65 \%)$ and least in the oil palm + maize + cassava treatment $(54.2 \%)$.

The oil palm + pueraria and oil palm + maize + maize treatments had $\mathrm{P}$ levels reduced to below $10 \mathrm{mg} \mathrm{P} \mathrm{kg}^{-1}$ soil by 2000 . At the $0-15 \mathrm{~cm}$ depth, oil palm + pueraria had the lowest $P$ values from 2000 to 2002. The decline in P level was consistent from 1999 to 2002 for both soil depths in the oil
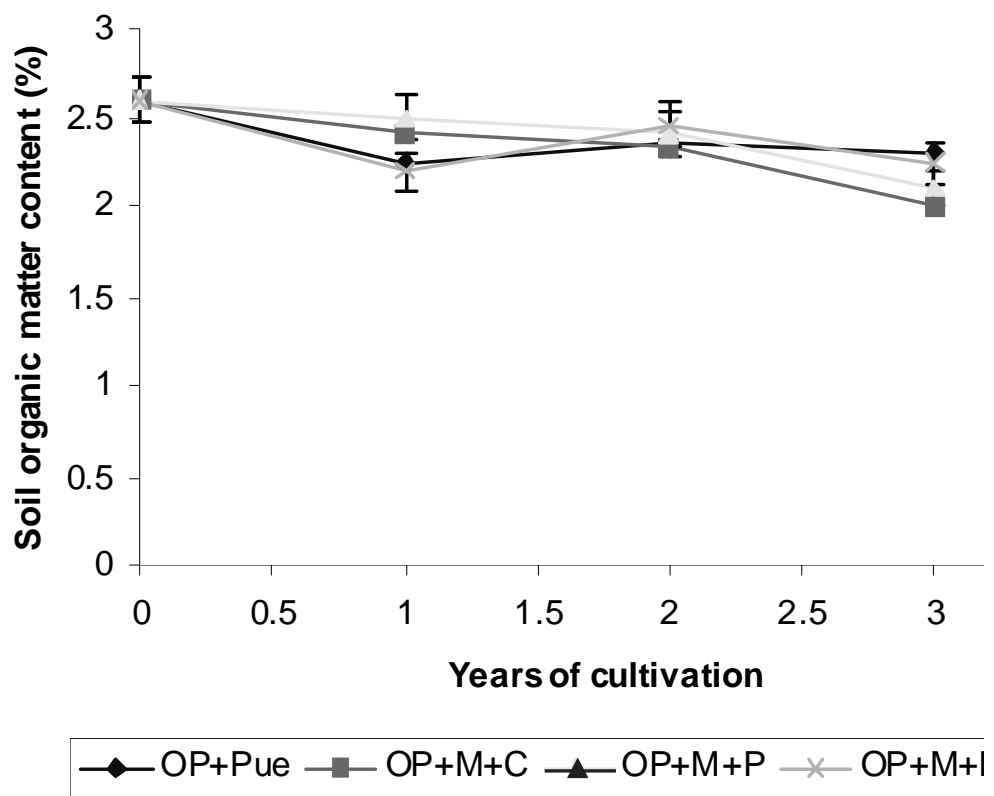

Fig. 1. Soil organic matter dynamics as affected by the various crop combinations: Oil palm + pueraria (OP + Pue), oil palm + maize + cassava $(O P+M+C)$, oil palm + maize + plantain $(O P+M+P)$, oil palm + maize + maize $(O P$ $+\mathrm{M}+\mathrm{M})$. 
TABLE 2

Effect of Intercropping Food Crops in Oil Palm on Dynamics of Soil Total Nitrogen (N) from 1999 to 2002

\begin{tabular}{lcccc}
\hline & \multicolumn{4}{c}{ Soil total N (\%) of cropping year } \\
Crop combination & 1999 & 2000 & 2001 & 2002 \\
\hline & & $0-15 \mathrm{~cm}$ soil depth \\
& & & & \\
Oil palm + pueraria & 0.21 & 0.19 & 0.21 & 0.19 \\
Oil palm + maize + cassava & 0.21 & 0.19 & 0.19 & 0.18 \\
Oil palm + maize + plantain & 0.21 & 0.20 & 0.21 & 0.17 \\
Oil palm + maize + maize & 0.21 & 0.18 & 0.18 & 0.16 \\
LSD $(P \leq 0.05)$ & $\mathrm{NS}$ & 0.04 & 0.04 & 0.03 \\
& & & & \\
& & & & \\
Oil palm + pueraria & 0.13 & 0.15 & 0.14 & 0.11 \\
Oil palm + maize + cassava & 0.13 & 0.15 & 0.14 & 0.10 \\
Oil palm + maize + plantain & 0.13 & 0.16 & 0.12 & 0.10 \\
Oil palm + maize + maize & 0.13 & 0.16 & 0.11 & 0.09 \\
LSD $(P \leq 0.05)$ & $\mathrm{NS}$ & 0.02 & 0.03 & 0.02 \\
CV $(\%)$ & & 6.33 & 16.55 & 15.40 \\
\hline
\end{tabular}

TABLE 3

Effect of Intercropping Food Crops in Oil Palm on Dynamics of Available Phosphorus from 1999 to 2002

Soil available $P\left(\mathrm{mg} \mathrm{kg}^{-1}\right)$ of cropping year

\begin{tabular}{|c|c|c|c|c|}
\hline Crop combination & 1999 & 2000 & 2001 & 2002 \\
\hline & \multicolumn{4}{|c|}{$0-15 \mathrm{~cm}$ soil depth } \\
\hline Oil palm + pueraria & 9.6 & 4.8 & 2.6 & 2.4 \\
\hline Oil palm + maize + cassava & 14.0 & 11.8 & 4.9 & 3.0 \\
\hline Oil palm + maize + plantain & 14.0 & 10.1 & 5.8 & 2.3 \\
\hline Oil palm + maize + maize & 13.5 & 7.7 & 6.3 & 1.9 \\
\hline \multirow[t]{2}{*}{$\operatorname{LSD}(P \leq 0.05)$} & 3.0 & 3.4 & 2.5 & 1.5 \\
\hline & \multicolumn{4}{|c|}{$15-30 \mathrm{~cm}$ soil depth } \\
\hline Oil palm + pueraria & 8.3 & 4.2 & 2.7 & 2.9 \\
\hline Oil palm + maize + cassava & 8.3 & 5.6 & 1.7 & 3.3 \\
\hline Oil palm + maize + plantain & 8.3 & 6.4 & 3.2 & 1.0 \\
\hline Oil palm + maize + maize & 8.3 & 3.8 & 1.2 & 2.1 \\
\hline $\operatorname{LSD}(P \leq 0.05)$ & NS & 2.5 & 2.2 & 2.0 \\
\hline
\end{tabular}




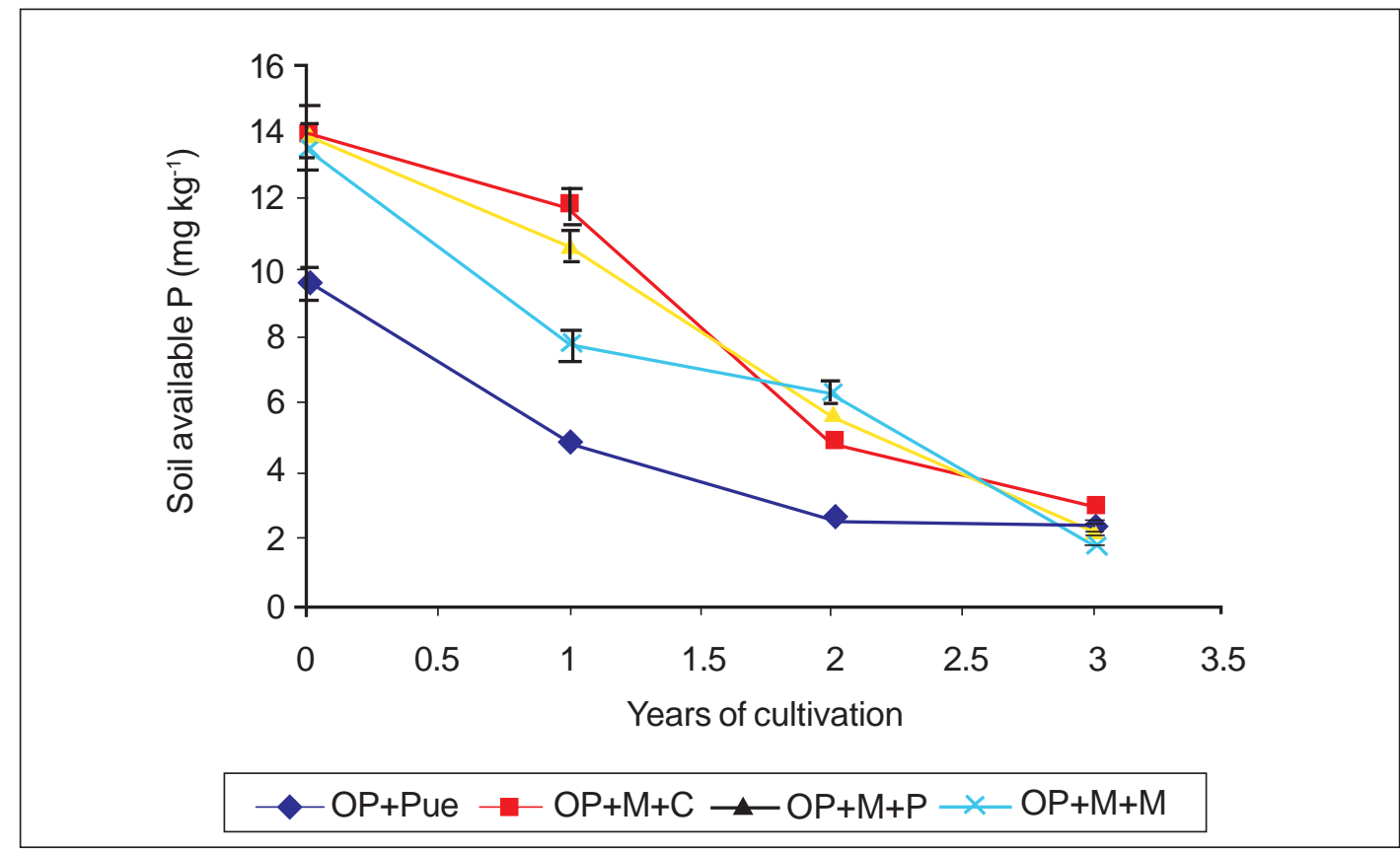

Fig. 2. Decline in soil $(0-15 \mathrm{~cm})$ available phosphorus (Bray-1 $\mathrm{P})$ with time of cultivation as affected by the various crop combinations: Oil palm + pueraria $(\mathrm{OP}+\mathrm{Pue})$, oil palm + maize + cassava $(\mathrm{OP}+\mathrm{M}+\mathrm{C})$, oil palm + maize + plantain $(O P+M+P)$, oil palm + maize + maize $(O P+M+M)$.

palm + maize + plantain plots. The mean available phosphorus level in the soils was highest in the cassava treatment and least in the pueraria treatment.

\section{Available potassium}

Available potassium levels declined in all treatments after the 1 st year of cropping, followed by gradual increase in subsequent years (Fig. 3; Table 4). The highest amount of available potassium was recorded in the treatment with pueraria at $0-15 \mathrm{~cm}$ depth. Potassium level declined from $108 \mathrm{mg} \mathrm{kg}^{-1}$ in 1999 to $88.8 \mathrm{mg} \mathrm{kg}^{-1}$ in 2002. The other cropping systems followed the same trend. The oil palm + maize + maize treatment had the lowest amount of available potassium $\left(65.6 \mathrm{mg} \mathrm{kg}^{-1}\right.$ soil $)$ at the end of 3 years of continuous cropping.

Available potassium levels in the $15-30 \mathrm{~cm}$ depth are generally lower than those at the 0-15 $\mathrm{cm}$ depth, but they followed the same trends in relation to the various treatments.

Effects of intercropping on the dynamics of oil palm nutrient uptake

Table 4 presents data on the oil palm leaf nutrient, using Frond No.17. None of the cropping systems significantly affected the NPK contents of the leaves.

Nitrogen content decreased with age of oil palm. Generally, the $\mathrm{N}$ content of the leaves were above the critical level of 2.5 per cent desired up to 30 months after planting (MAP), but dropped below critical levels for all treatments by 36 MAP. The levels of $\mathrm{P}$ for oil palm + pueraria and oil palm + maize + cassava were maintained above the critical level of 0.15 over 36 months.

Potassium leaf nutrient contents followed the same trend as nitrogen. The levels of $\mathrm{K}$ in the leaves dropped below the deficiency threshold 


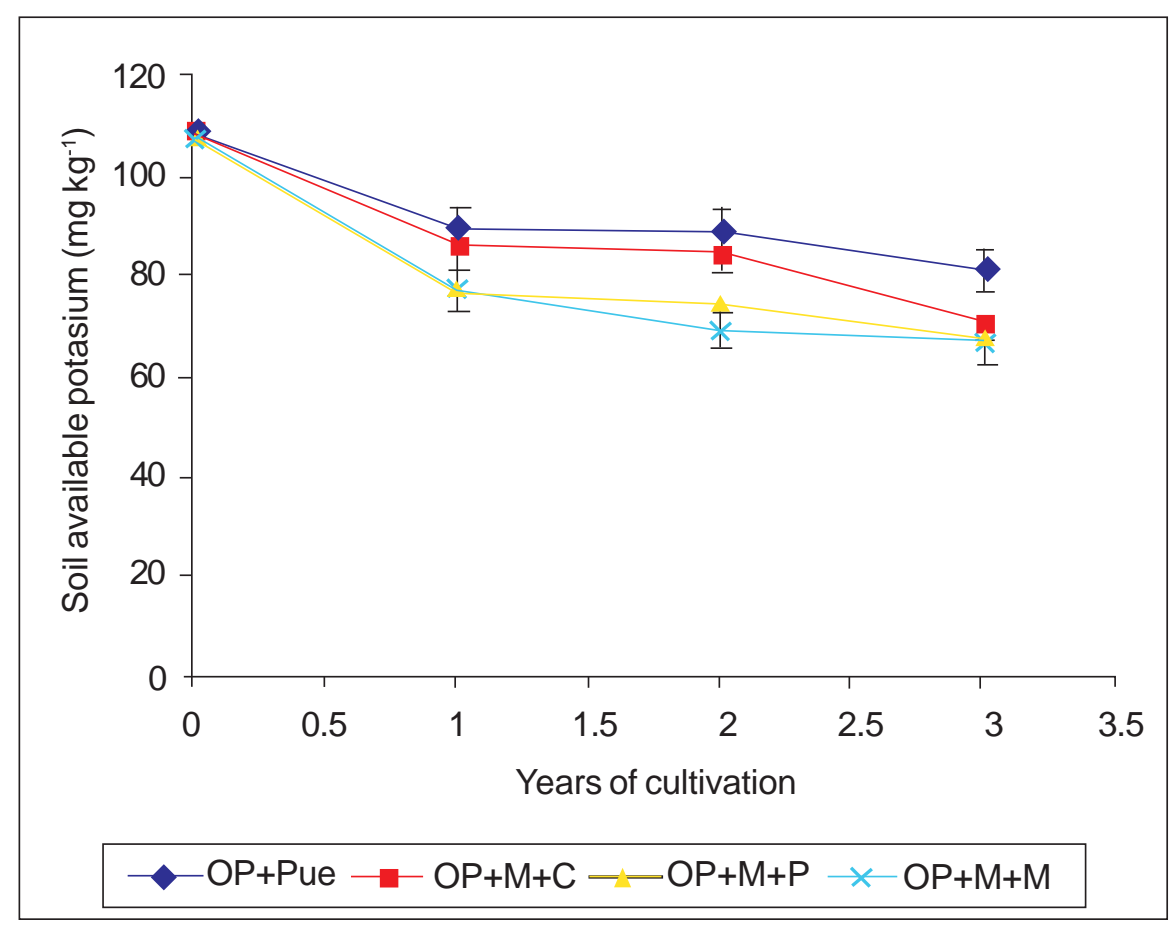

Fig. 3. Available potassium dynamics as affected by various crop combinations: Oil palm + pueraria $(\mathrm{OP}+\mathrm{Pue})$, oil palm + maize + cassava $(O P+M+C)$, oil palm + maize + plantain $(O P+M+P)$, oil palm + maize + maize $(O P+$ $M+M)$.

of 1.0 by 36 MAP for all treatments.

Cropping system did not significantly affect the leaf nutrient content of the oil palm.

\section{Soil moisture status}

Percentage soil moisture status was affected by the various cropping systems during the dry season (Table 5). In the upper horizon, differences in moisture status among the treatments were not significant. Generally, oil palm with the pueraria cover crop retained more soil moisture than the oil palm-food crop intercrops at $0-15 \mathrm{~cm}$ depth.

\section{Light interception by the oil palm}

Table 6 shows daily light interception by the oil palm in various cropping systems. Light interception varied with the intercrops. The oil palm-cassava intercrop intercepted the least percent light. Oil palm + maize + maize intercepted light significantly higher $(P \leq 0.05)$ than the other treatments.

\section{Discussion}

\section{Nutrient dynamics}

The difference between the sole oil palm with pueraria cover crop and the three oil palm-food intercrops concerning the capture and use of growth factors and resources was significant. Generally, soil $p \mathrm{H}$ values were very acidic and would require some improvement. Though oil palm grows well in acidic soils, slightly improved $p \mathrm{H}$ levels may improve nutrient availability and uptake (Hartley, 1988). Values for soil $p \mathrm{H}$, organic matter and total nitrogen contents for the plantain treatment were lower than those for any other crop by 2002. Plantain takes up much nutrients such as $\mathrm{K}, \mathrm{Ca}$, and $\mathrm{Mg}$ that results in the release of $\mathrm{H}^{+}$; hence, low $p \mathrm{H}$ values (Fox, 1989). 
TABLE 4

Effect of Intercropping Oil Palm with Food Crops on Dynamics of Leaf Total Nitrogen, Phosphorus and Potassium

\begin{tabular}{|c|c|c|c|c|c|}
\hline \multirow[t]{2}{*}{ Crop combination } & \multicolumn{4}{|c|}{ Months after planting } & \multirow[b]{2}{*}{36} \\
\hline & 6 & 18 & 24 & 30 & \\
\hline & \multicolumn{5}{|c|}{ Percentage leaf nitrogen } \\
\hline Oil palm + pueraria & 3.0 & 3.1 & 2.7 & 3.0 & 2.3 \\
\hline Oil palm + maize + cassava & 3.3 & 3.1 & 2.6 & 2.6 & 2.3 \\
\hline Oil palm + maize + plantain & 3.2 & 3.2 & 2.7 & 2.8 & 2.0 \\
\hline Oil palm + maize + maize & 3.2 & 3.1 & 2.5 & 3.0 & 2.4 \\
\hline $\operatorname{LSD}(P=0.05)$ & NS & NS & 0.2 & 0.3 & 0.3 \\
\hline \multirow[t]{2}{*}{$\mathrm{CV}(\%)$} & 20.25 & 17.69 & 20.59 & 8.54 & 10.36 \\
\hline & \multicolumn{5}{|c|}{ Percentage leaf phosphorus } \\
\hline Oil palm + pueraria & 0.35 & 0.29 & 0.32 & 0.31 & 0.26 \\
\hline Oil palm + maize + cassava & 0.34 & 0.26 & 0.30 & 0.32 & 0.31 \\
\hline Oil palm + maize + plantain & 0.34 & 0.31 & 0.33 & 0.32 & 0.15 \\
\hline Oil palm + maize + maize & 0.33 & 0.31 & 0.31 & 0.32 & 0.16 \\
\hline LSD $\quad(P=0.05)$ & NS & 0.04 & 0.03 & NS & 0.10 \\
\hline \multirow[t]{2}{*}{$\mathrm{CV}(\%)$} & 10.69 & 7.79 & 8.84 & 9.78 & 9.43 \\
\hline & \multicolumn{5}{|c|}{ Percentage leaf potassium } \\
\hline Oil palm + pueraria & 1.7 & 1.7 & 1.8 & 0.9 & 0.9 \\
\hline Oil palm + maize + cassava & 1.7 & 1.5 & 1.7 & 1.2 & 0.8 \\
\hline Oil palm + maize + plantain & 1.9 & 1.7 & 1.8 & 1.5 & 0.9 \\
\hline Oil palm + maize + maize & 1.7 & 2.0 & 1.8 & 1.1 & 0.8 \\
\hline $\operatorname{LSD}(P=0.05)$ & NS & 0.4 & NS & 0.5 & NS \\
\hline $\mathrm{CV}(\%)$ & 24.54 & 13.23 & 21.04 & 28.47 & 19.62 \\
\hline
\end{tabular}

TABLE 5

Percentage Soil Moisture of Various Intercropped Combinations During a Dry Season

Soil moisture content (\%) at various periods

\begin{tabular}{lccc} 
Crop combination & Dec. 1999 & Jan. 2000 Feb. 2000 \\
\hline & & 0-30 cm soil depth \\
Oil palm + pueraria & 7.10 & 7.65 & 5.60 \\
Oil palm + maize + cassava & 7.70 & 5.33 & 2.49 \\
Oil palm + maize + plantain & 9.10 & 5.33 & 2.25 \\
Oil palm + maize + maize & 11.40 & 5.81 & 2.75 \\
LSD $(P \leq 0.05)$ & 1.50 & 0.50 & 0.80 \\
& & & 3.68 \\
Oil palm + pueraria & & $30-60$ cm soil depth \\
Oil palm + maize + cassava & 10.97 & 9.60 & 3.26 \\
Oil palm + maize + plantain & 10.94 & 6.70 & 3.60 \\
Oil palm + maize + maize & 11.68 & 7.73 & 4.28 \\
LSD $(P \leq 0.05)$ & 13.31 & 8.22 & 0.80 \\
\hline
\end{tabular}


TABLE 6

Effect of Intercropping Oil Palm with Food Crops on Percent Light Interception by Oil Palm

\begin{tabular}{lcccccc}
\hline \multicolumn{7}{c}{ Time of the day } \\
Crop combination & $\begin{array}{c}10.30 \\
\text { a.m. }\end{array}$ & $\begin{array}{c}11.30 \\
\text { a.m. }\end{array}$ & $\begin{array}{c}12.30 \\
\text { p.m. }\end{array}$ & $\begin{array}{c}13.30 \\
\text { p.m. }\end{array}$ & $\begin{array}{c}14.30 \\
p . m .\end{array}$ & $\begin{array}{c}15.30 \\
\text { p.m. }\end{array}$ \\
\hline & & & $\%$ & & & \\
Op + Pue & 52.2 & 51.5 & 49.5 & 45.5 & 44.4 & 43.6 \\
Op+Ma+Ca & 46.6 & 44.0 & 42.0 & 39.1 & 34.7 & 31.9 \\
Op + Ma + Pl & 52.3 & 46.2 & 45.8 & 46.3 & 46.9 & 47.0 \\
Op+Ma+Ma & 49.0 & 59.2 & 65.0 & 60.0 & 54.9 & 52.9 \\
\hline LSD $(P \leq 0.05) b$ & NS & NS & 11.9 & 10.9 & 12.8 & 12.0 \\
CV $(\%)$ & 23.4 & 16.8 & 14.9 & 14.3 & 17.7 & 17.1 \\
\hline
\end{tabular}

Op = Oil palm; Pue $=$ Pueraria $; \mathrm{Ma}=$ maize

According to Hamdan, Tarmizi \& Mohd Tayeb (1998), soil test values lower than the critical nutrient levels of $0.20 \%, 15 \mathrm{mg} \mathrm{kg}^{-1}$, and $0.30 \mathrm{cmol}$ $\mathrm{kg}^{-1}$ for total $\mathrm{N}$, available $\mathrm{P}$, and exchangeable $\mathrm{K}$ would require about $100 \mathrm{~kg} \mathrm{~N}, 40 \mathrm{~kg} \mathrm{P}_{2} \mathrm{O}_{5}$, and 100 $\mathrm{kg} \mathrm{K} 2 \mathrm{O}$, respectively, to attain optimum site yield potential for oil palm.

The pueraria cover crop provided continuous cover to the soil, which could have reduced evaporation loss. Besides, competition for water by weeds was suppressed by the pueraria cover crop. The major avenue through which water could be lost was by transpiration by the pueraria itself. However, during the dry season, most pueraria leaves senescenced, providing dry mulch cover for the soil that could have preserved some soil moisture. There was, therefore, limited evapotranspiration. The amount of nutrients needed to attain the maximum site yield potential would vary according to the palm growth, size and nutrition, yield level, site soil properties and characteristics (Foster et al., 1986). A steep slope accompanied by high annual rainfall may be expected to reduce the efficiency of nutrient uptake (Kee \& Chew, 1996).

Protecting the organic matter in topsoil from erosion, establishment of cover crops, and soil moisture conservation will lead to efficient fertilizer use through inorganic fertilizer interactions with mulch (Chan, Lim \& Ahmed, 1993). Maize was not grown during the dry season. The maize stubbles and residues of the major season, which littered the soil surface, also served as dry mulch cover for the soil with similar consequences as the dry senescenced pueraria leaves. Although soil under oil palm + maize + maize was apparently more depleted in nutrients than the other crop combinations (Table 3), it had better moisture and nutrient conservation practice. Nutrient uptake by the palm will be higher if nutrient losses are minimized through better soil conservation measures (Kee \& Chew, 1996) and improved soil fertility through organic matter amendment and nutrient cycling (Chan et al., 1993; Khalid, 1997).

\section{Plant tissue nutrient content}

Plant tissues are analyzed to determine the nutrient content in the sample to use the data to improve fertilizer use efficiency and to confirm visual symptoms (Pushparajah \& Chew, 1997). Basically, leaf analysis indicates the nutritional status of the crop at the time of sampling. The nutrient content of oil palm leaves fell below the 
critical nutrient levels of 2.50, 0.15 and 2.00 per cent for N, P, and K, respectively (Dierolf, Farhust \& Mutert, 2001), after 30 months possibly because of high nutrient demand exceeding supply by the soil. This means the need was to improve soil nutrient content by applying fertilizer after 30 month' growth. The leaf tissue phosphorus content in the pueraria + oil palm treatment was maintained above the critical level probably because of improved $P$ supply as a result of increased supply of organic substances from decomposing pueraria cover.

According to Follett, Murphy \& Donahue (1981), production of organic acids from organic matter seems to be a major pathway of solubilization of insoluble phosphorus compounds. The oil palm + maize + cassava also maintained $\mathrm{P}$ level in plant tissue above the critical level probably because of the association of mycorrhiza with the roots of cassava; thus, improving the solubilization and availability of phosphorus to oil palm (Atayese \& Laisu, 2001). The oil palm is recognized as having a high demand for nutrients. Nutrients that are removed continuously through the harvested fresh fruit bunch, or sequestered in the standing biomass, need replacement if soil nutrient reserves are not to be depleted (Tarmizi \& Mohd Tayeb, 2006).

Moisture conservation and solar interception by oil palm

The ability of the cropping systems to conserve soil moisture might have influenced the differences in light intercepted. Higher percentage of light was intercepted in the morning when little water was transpired from the plant. This may be due to increased light reaching the lower and middle strata at an incident angle in the morning. However, as the day advanced, light was transmitted through the various strata vertically to the ground. For the treatment with maize + maize, under which the highest percentage of moisture was preserved, the oil palm leaves intercepted the highest percentage of light. The cassava treatment, with the least percentage soil moisture preserved, also registered the least percentage light intercepted.

Percentage light interception by the oil palm + maize + maize treatment was highest. Shading might have contributed to the control of the less shade-tolerant weed types, especially the broadleaved weeds under the maize + maize association with oil palm.

Cassava took much longer time to form a canopy. Until the canopy was formed, there were enough growth factors, especially available light, for the growth of weeds. The same was for the oil palm-plantain association.

Plantain has much wider spacing; so much light penetrated it, which enhanced the infestation of weeds.

\section{Conclusion}

Sole oil palm with pueraria cover crop (the control) was superior to the other three oil palm-food intercrops regarding the capture and use of nutrients, and soil water conservation. In the surface soil, phosphorus dynamics for oil palm with cassava after maize, and oil palm with maize after maize treatments were, however, superior to the oil palm with pueraria treatment.

Oil palm with maize after maize equalled the oil palm with pueraria cover crop in soil moisture conservation, and also intercepted light more. Oil palm with maize after maize was, therefore, the treatment that could be recommended to farmers; because the small-scale oil palm farmers would always do intercropping at the initial stages to make maximum use of the land.

\section{Acknowledgement}

The authors are thankful to the staff of Agronomy Division, CSIR-OPRI, Kusi-Kade, Ghana, who helped with the data collection. This paper is published with the permission of the Director, CSIR-OPRI, Ghana.

\section{REFERENCES}

Anon. (1988) Notes on the oil palm (memoir). OPRI. Kusi-Kade. 12 pp. 
Atayese, M. O. \& Laisu, M. O. (2001) Arbuscular mycorrhizal fungi, weeds and earthworm interactions in the restoration of soil fertility in the Guinea savanna region of Nigeria. Moor Journal of Agricultural Research 2, 103-109.

Black, C. A. (1965) Methods of soil analysis. Agronomy 9, 1179-1237.

Chan, K. W., Lim, K. C. \& Ahmad, A. (1993) Intensification of oil palm cropping through interactions between inorganic and organic fertilizers. In Proceedings of the PORIM International Palm Oil Congress - Update and Vision - Agriculture Module (ed. B. S. Jalani, D. Arifin, N. Rajanaidu, D. Mohd Tayeb, K. Paranjothy, W. Mohd Basri, I. E. Henson and K. C. Chang). PORIM, Bangi. pp. 329-342.

Chew, P. S., Kee, K. K., Goh, K. J., Quah, Y. T. \& Tey, S. H. (1992) Fertilizer management in oil palm. In Proceedings of the International Conference on Fertilizer Usage in the Tropic (ed. B. Aziz.). Malaysian Society of Soil Science, Kuala Lumpur. pp. 43-67.

Dierolf, T., Farhurst, T. \& Mutert, E. (2001) Soil fertility kit: A toolkit for aid upland soil fertility management in southeast Asia. Potash and Phosphate Institute (PPI), ProRLK, GTZ, Gmbh, Singapore. 149 pp.

Follett, R. H., Murphy, L. S. \& Donahue, R. L. (1981) Fertilizers and soil amendments. PrenticeHall, Inc., Eaglewood Cliffs, N. J. pp. 84-159.

Foster, H. L., Tarmizi, A. M., Mohd Tayeb, D., Chang, K. C., Zin, Z. Z. \& Halim, H. (1986) Fertilizer recommendations for oil palm in Peninsular Malaysia (first approximation). PORIM Technology No. 13:42.

Fox, R. L. (1989) Banana. In Detecting mineral nutrition deficiencies in tropical and temperate crops (ed. D. L. Plucknett and H. . Sprague). Westview, Boulder, CO, USA.

Hamdan, A. B., Tarmizi, A. M. \& Mohd Tayeb, D. (1998) Empty fruit bunch mulching and nitrogen fertilizer amendment: The resultant effect on oil palm performance and soil properties. PORIM Bulletin No. 37, 1-14.

Hartley, C. W. S. (1988) The oil palm. Longman, London. 761 pp.

Kee, K. K. \& Chew, P. S. (1996) Nutrient losses through surface runoff and soil erosionimplications for improved fertilizer efficiency in mature oil palms. In: D. Ariffin, W. Mohd Basri,
D. Mohd Tayeb, K. Paranjothy, N. Rajanaidu, S.C. Cheah, K.W. Chang and S. Ravigadevi (ed.). Proceedings of the 1996 PORIM International Palm Oil Congress - Agriculture Conference. PORIM, Bangi. pp. 153-169.

Khalid, H. (1997) Nutrient cycling in an oil palm (Elaeis guineensis Jacq.) plantation: Residue decomposition and implication for management (PhD Thesis). Faculty of Biological Sciences, University of Exeter, United Kingdom. 298 pp.

Nelson, D. W. \& Sommers, L. W. (1982) Total carbon, organic carbon and organic matter. In Methods of soil analysis, Part 2, 2nd edn (ed. A. L. Page, R. H. Miller and D. R. Keeney). Agronomy 9, 301-312.

Ng, S. K. \& Thamboo (1967) Nutrient contents of oil palms in Malaya. I. Nutrients required for reproduction: Fruit bunch and male inflorescences. Malaysian Agricultural Journal 46, 3-45.

Norman, D.W. (1974) Rationalizing mixed cropping under indigenous conditions: The example of Northern Nigeria. Journal of Development Study 11, 3-21.

Nuertey, B. N. (2000) Studies into oil palm-based cropping systems in Ghana (Ph D Thesis). Submitted to the Board of Graduate Studies in partial fulfilment of the requirements for the award of the degree of Doctor of Philosophy in Crop Science.

Pushparajah, E. \& Chew, P. S. (1997) Utilization of soil and plant analyses for plantation agriculture. In Proceedings of the Malaysian Seminar on the Fertility and Management of Deforested Land (ed. J. T. Henry and L. Liau). Society of Agricultural Scientists, Sabah, Kotakinabam, Malaysia. pp. 177199.

Rees, A. R. (1989) Climatic limitations to yield in the oil palm. Proceedings of the International Conference on Palms and Palm Products. NIFOR, Benin City, Nigeria.

Rowell, D. L. (1994) Soil science: Methods and applications. Longman Scientific and Technical. John Willey and Sons Inc., NY. pp. 157-158.

Sparnaaij, L. D. (1991) The analysis of 1991 oil palm intercropping survey in West Africa. The Netherlands. 15 pp.

Tarmizi, A. M. \& Mohd Tayeb, D. (2006) Nutrient demands of Tenera oil palm planted on inland soils of Malaysia. Journal of Oil Palm Research 18, 204209. 